\title{
Investigation of reinforced concrete jacketed columns under different loading conditions
}

\author{
Praveen Anand $^{1 *}$, Ajay Kumar Sinha ${ }^{2}$ and Chandan Kumar ${ }^{1}$ \\ Research Scholar, Department of Civil Engineering, National Institute of Technology, Patna, Bihar, 800005, India ${ }^{1}$ \\ Professor, Department of Civil Engineering, National Institute of Technology, Patna, Bihar, 800005, India²
}

Received: 04-June-2021; Revised: 17-August-2021; Accepted: 18-August-2021

(C)2021 Praveen Anand et al. This is an open access article distributed under the Creative Commons Attribution (CC BY) License, which permits unrestricted use, distribution, and reproduction in any medium, provided the original work is properly cited.

\begin{abstract}
The behaviour of existing buildings depends upon the original structural design and the inadequacies associated with it. But, over the time such types of buildings become susceptible to the existing load and to the loads that it is going to be exposed to in the near future. Therefore, it becomes immensely important to strengthen or retrofit the vulnerable members to keep the whole structure safe. The objective of this study was to determine the strength enhancement of an existing Reinforced Concrete (RC) column after RC jacketing. In order to achieve the objective, the present study investigates the effectiveness of RC jacketing by evaluating the existing column as well as the strengthened column under three loading conditions viz. pure compression, eccentric compression and pure bending. The simulation has been performed in a finite element software ABAQUS whose results have been compared with the previously available experimental works. The results obtained post-simulation indicate a significant increase in the load carrying capacity of the strengthened columns under all three loading conditions.
\end{abstract}

\section{Keywords}

Strengthening, RC column, Jacketing, Retrofitting.

\section{Introduction}

Existing buildings may need to be strengthened to avoid the damage related to structures due to an increase in floor loads, inadequate detailing, a timely revision of design codes, etc. [1-3]. Retrofitting requires modifying an existing structure to make it more durable and resilient for the desired use. Several techniques for strengthening the existing buildings, such as enhancing the stiffness, improving discontinuity or irregularity in the distribution of stiffness of a building, have been examined and analysed in recent years. In the construction field, Reinforced Concrete (RC) is still the most widely used material being used [4]. Load bearing members such as beam and column largely utilises concrete and steel. But, due to poor construction practices and deterioration of materials, such members sometimes need to be strengthened. This paper covers the strengthening of RC columns. Various techniques such as RC jacketing, steel jacketing, Fibre Reinforced Polymer (FRP) jacketing exist which are being used worldwide to strengthen the columns [2].

*Author for correspondence

957
One of the most influential techniques to retrofit the column is RC jacketing. This type of strengthening improves the axial, shear strength, and flexural capacity of columns, however, the increase in ductility is relatively less [2]. Secondly, it is easy to construct and install, therefore, is the most widely used technique of retrofitting all over the world. Besides RC jacketing, steel jacketing is also a widely used technique to strengthen the columns. Seismic performance of RC columns strengthened by externally wrapping the steel plates resulted in an increased bearing capacity of about $80 \%$ than the unstrengthened column [5]. The use of steel tubes as a retrofitting tool on the slender RC column has been proven to be very effective in enhancing the load bearing capacity, ductility and stiffness [6]. The effect of steel jacketing on the seismic performance of a 6 story RC building by jacketing the columns was investigated [7]. The results of the same indicated that the axial and flexural strength of an individual column increases by $184 \%$ and $261 \%$, respectively, whereas the lateral strength of the building increases by $127 \%$ and $74 \%$ along $\mathrm{X}$ and $\mathrm{Y}$ direction respectively. Apart from RC and steel jacketing, another technique that has become the hotspot of strengthening practices is 
FRP wrapping. Different types of fibers such as Glass Fibre Reinforced Polymer (GFRP), Carbon Fibre Reinforced Polymer (CFRP), Hybrid Fibre Reinforced Polymer (HFRP) are available. Experimental analysis of an I beam with GFRP pultrudes and CFRP lamination on the flanges indicated linear elastic behaviour and significant shear deformation [8]. Performance of GFRP wrapped RC column under axial load indicated an increase of $31.86 \%$ in the axial load carrying capacity with $25 \mathrm{~mm}$ corner radii and $15.06 \%$ for columns with sharp corners [9]. FRPs with Near Surface Mounted (NSM) rebars is another strengthening method that has proven to be effective when flexural strength is considered. An increase in the NSM reinforcement percentage from $0.16 \%$ to $1 \%$ of the total cross-sectional area leads to a $28 \%$ increase in the lateral capacity of the columns [10].

Besides the advantages associated with these strengthening techniques, each method has certain disadvantages. RC jacketing increases the crosssectional area, thus reducing the carpet area. Steel jacketing requires heavy equipment for the handling process and also changes the aesthetic appearance. FRP jacket, though fast and efficient technique, however, it shows irregular plastic behaviour and possesses inadequate fire resistance capacity. Secondly, the use of FRP is limited only in some countries and industries. Analysis on a full-scale rectangular column indicated that FRP retrofit approach based on American Concrete Institute and Turkish codal provisions are not feasible and conservative, however, European retrofit approach is more economical and realistic [3].

The drawbacks associated with FRP and steel jacketing technique motivated the need to investigate a more feasible and effective method for strengthening. $\mathrm{RC}$ jacketing though reduces the carpet area and is time-consuming process, however is the most practical solution for strengthening of columns. This paper primarily focuses on the application of the $\mathrm{RC}$ jacket around the existing column and its influence on the load bearing of the column. The objective of the study was to find the additional load that the strengthened column would be able to carry post RC jacketing. To achieve this objective, an existing column is confined with an additional layer of RC jacket and analysed under pure compression, eccentric compression and pure bending. The thickness of the jacket is kept at $100 \mathrm{~mm}$. The simulation for the existing column and strengthened column has been carried out in a finite element ABAQUS which is a direct and economic method and helps in making a comparative analysis. The increase in the load carrying capacity is observed from the load vs displacement curves for axial and eccentric loading and moment vs rotation curve for pure bending.

\section{Literature review}

Research fraternity investigating the application of several retrofitting techniques to the existing structures has proposed. It is developed and successfully applied several methods which have shown tremendous success, but revealed various drawbacks as well, which has motivated researchers to improve current practices. Concrete Jacketing has proved to be a very effective method in seismic retrofitting of columns which help in the conversion of strong beam weak column into a strong column and weak beam thus inducing the formation of hinges in beams and not in columns during the formation of a mechanism [11]. With this strong column weak beam principle, the shear capacity of the column also gets enhanced. The fundamental advantage of this technique is that it increases the shear and flexural capacity and is easy to construct. Secondly, a substantial increase in ductility, as well as stiffness of the section can be obtained depending upon the amount of reinforcement and type of concrete added to the jacket [12]. In another study, $25 \mathrm{~mm}$ and $35 \mathrm{~mm}$ jacket thickness with normal strength concrete and ultrahigh-performance self-compacting concrete respectively, indicated an increase of two to three times in the ultimate load carrying capacities of jacketed column [13]. The effect of combined loading i.e., axial loading and lateral cyclic loading was investigated. The strengthened columns with ultrahigh performance ferro-cement laminate showed significant improvement in the bearing capacity as compared to the un-strengthened specimen [14-15]. The influence of jacket height on RC columns subjected to cyclic loading was investigated [16]. Columns retrofitted with a jacket height of $h / 4$ and $h / 2$, were investigated ( $h$ being the height of the column). It was observed that the variation in the lateral load carrying capacity of the columns with $\mathrm{h} / 2$ jacket height was above $23 \%$ than the column with a jacket height of $\mathrm{h} / 4$.

To analyse the bonding between new and old concrete, and to establish a monolithic behaviour for the entire concrete, surface of the concrete column was roughened with an electric hammer [17]. Similarly, to assess the bond strength in shear and tension, slant shear test, pull-off tests and pull-out tests were performed [18-20]. It was concluded that all the tests were effective for reviewing the bond strength. The 
impact of surface preparation, the use of epoxy resins and steel connectors was conducted [21-23]. The test results were analysed and it was concluded that a decent bond can be established by casting a new concrete layer against the existing concrete without using any bonding agent. A new material Engineered Cementitious Composites (ECC) having many favourable properties such as damage tolerance, delamination resistance, etc. It has been found very effective in improving the interfacial bond performance with the substrate concrete [4]. Use of ECC in combination with high-strength polyethylene fibres to develop fibre RC jackets was examined [24]. The results showed that under the effect of axial load, the jackets with no fibre exhibited brittle behaviour while ductile behaviour was observed with the jackets containing stirrups and fibres. Similar to the interface treatment, different researchers have used different thickness of RC jacket based on their suitability. Table 1 summarizes the details of the dimensions of the reference column and thickness of $\mathrm{RC}$ jackets adopted by the researchers.

Table 1 Summary of thickness of jackets from previous research

\begin{tabular}{|c|c|c|c|}
\hline Reference & $\mathbf{b}_{\mathbf{e}}$ & $\mathbf{d}_{\mathrm{e}}$ & $\mathbf{t}_{\mathbf{j}}$ \\
\hline Kaliyaperumal and Sengupta [1] & $150 \mathrm{~mm}$ & $150 \mathrm{~mm}$ & $50 \mathrm{~mm}$ \\
\hline Tayeh et al. [13] & $150 \mathrm{~mm}$ & $150 \mathrm{~mm}$ & $25 \mathrm{~mm} \& 35 \mathrm{~mm}$ \\
\hline Alcocer [25] & $304.8 \mathrm{~mm}$ (12in) & $304.8 \mathrm{~mm}(12 \mathrm{in})$ & $101.6 \mathrm{~mm}(4 \mathrm{in})$ \\
\hline Júlio et al.[26] & $200 \mathrm{~mm}$ & $200 \mathrm{~mm}$ & $35 \mathrm{~mm}$ \\
\hline Vandoros and Dritsos [27] & $250 \mathrm{~mm}$ & $250 \mathrm{~mm}$ & $70 \mathrm{~mm}$ \\
\hline Lampropoulos and Dritsos [28] & $200 \mathrm{~mm}$ & $200 \mathrm{~mm}$ & $35 \mathrm{~mm}$ \\
\hline \multirow{2}{*}{$\begin{array}{l}\text { Al-Dwaik } \\
\text { Armouti[29] }\end{array}$} & $700 \mathrm{~mm}$ & $700 \mathrm{~mm}$ & $125 \mathrm{~mm}$ \\
\hline & $550 \mathrm{~mm}$ & $550 \mathrm{~mm}$ & $75 \mathrm{~mm}$ \\
\hline Dritsos and Moseley [30] & $250 \mathrm{~mm}$ & $250 \mathrm{~mm}$ & $75 \mathrm{~mm}$ \\
\hline Anand and Sinha [31] & $300 \mathrm{~mm}$ & $300 \mathrm{~mm}$ & $100 \mathrm{~mm}$ \\
\hline
\end{tabular}

Where, $b_{e}, d_{e}$ being width and depth of the existing column while $t_{j}$ is the thickness of the jacket

Numerous methods and techniques have been studied and practiced in recent years to strengthen the existing structures. On the basis of the literature review, it has been observed that the experimental or numerical behaviour of the jacketed column is less defined. Unresolved issues regarding the capacity of the strengthened column after jacketing exist, such as finding the increase in load carrying capacity after jacketing. Secondly, the effect of adding new elements i.e., jacketing elements on the overall performance of the column under different loading conditions is the area that lacks enough research and understanding. Although several pieces of research have been carried out in the past by varying the thickness of the jacket as stated in Table 1, optimum thickness of the jacket to be provided is still undefined. Most of the researches focus on strengthening the undamaged column. Enough research is not available which shows the effect of jacketing on damaged columns. Lastly, most of the experimental analysis of the column and jackets considered the prototype dimensions of the specimens. However, columns with such small-scale dimensions are not considered in practical situations. Due to the limitations of the testing facilities, analysis of standard full-scale is scarce and hence their analysis can be done through simulation.

\section{Methodology}

The methodology involves modelling a column having a cross-section of $300 \mathrm{~mm} \times 300 \mathrm{~mm}$ with $3 \mathrm{~m}$ length in a Finite Element tool ABAQUS. The mathematical results obtained from the previous analysis [31] for the $\mathrm{RC}$ column confined with RC jacket under axial loading have been used. For analysing the columns under different loading conditions, the experimental test setup [1] has been modelled. Columns under eccentric compression have been analysed for the eccentricity value (e) of $50 \mathrm{~mm}$ and $100 \mathrm{~mm}$ for reference model and the jacketed model respectively. To validate the model, the column having a crosssection of $150 \mathrm{~mm} \times 150 \mathrm{~mm}$ with $50 \mathrm{~mm}$ jacket thickness has also been modelled and analysed. The experimental results obtained under the axial loading for the three specimens [1] have been used for validating the model. After the validation process is complete, the same analysis has been carried out for the columns with $3 \mathrm{~m}$ length. The sectional sketch describing the dimensions and reinforcement details of the existing column is presented in Figure 1, whereas the dimensions and reinforcement details for the jacket with $100 \mathrm{~mm}$ thickness are shown in Figure 2. The area of reinforcement in the existing column and the jacket has been considered as $1 \%$ of the gross crosssectional area. The reinforcement provided for the 
existing column consists of 8-12\# bars and 16-14\# bars for the RC jacket. The spacing of the stirrups in the existing column has been kept at $200 \mathrm{~mm}$, whereas it is $100 \mathrm{~mm}$ for the $\mathrm{RC}$ jacket.

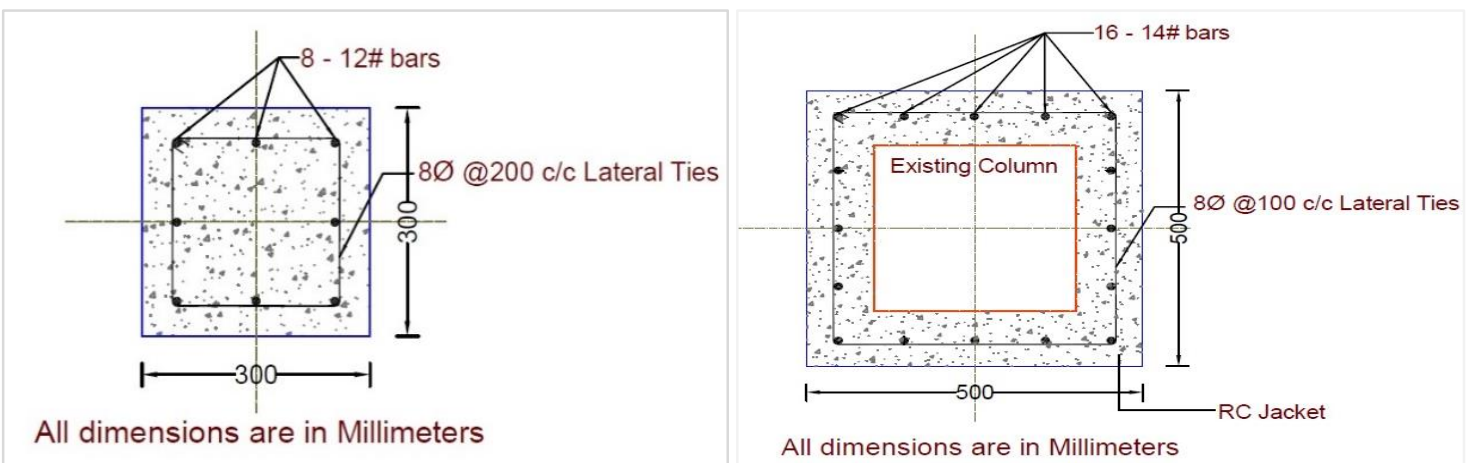

Figure 1 Cross-section of the existing column

Figure 2 Cross-section of RC jacket

\section{Modelling and simulation}

The current modelling and simulation were carried out using a finite element tool ABAQUS, which offers a very precise element library for modelling compressive plasticity and isotropic elasticity to approximate concrete behaviour. The Concrete Damaged Plasticity (CDP) model for simulation was used by adopting C3D8R brick element. The standard plasticity model was used for modelling the steel element by using T3D2 truss element. The embedded element technique to reflect the connection between concrete and steel was adopted, where the "guest" elements of the reinforcing bars are embedded in the "host" concrete elements. In this analysis column were fixed (with all the degree of freedom taken as zero) at the bottom while the top end was kept free in all directions where the application of load is supposed to take place. Step 1 is where the load is generated. The magnitude of the load is scaled up during the length of step 1 as the loading is generally static. The accelerated option alters the value of loading at a constant rate. The mesh element form that has been assigned to this model is "HEX," and the technique employed is "structured.". The constraints used are embedded element and Multi-Points Constraints (MPC) coupling. The embedded element technique is used to embed the reinforcement inside the host element which is concrete. The reaction values that will be generated on the multiple nodes on column faces will be extracted using MPC coupling.

\section{Validation}

In order to validate the finite element model used in this study, a column tested by Kaliyaperumal and Sengupta [1] was modelled and analysed. The existing column was referred as the reference specimen while the jacketed column was referred as retrofitted column. Three specimens were created for the reference column and three for the retrofitted column. All the models were tested for compression test. The cross-section of the existing column was 150 by 150 $\mathrm{mm}$ as shown by the finite element model in Figure 3 and the stirrups are placed at an interval of $150 \mathrm{~mm} \mathrm{c} / \mathrm{c}$. Similarly, the cross-section of the retrofitted specimen with $50 \mathrm{~mm}$ jacket thickness was 250 by $250 \mathrm{~mm}$ as shown by the finite element model in Figure 4 and stirrups are placed at an interval of $75 \mathrm{~mm} \mathrm{c} / \mathrm{c}$. The mean compressive strength ( $\mathrm{fcm})$ used for the reference specimen that is Pure Compression Original (PCO1), PCO2 and PCO3 were $23 \mathrm{Mpa}, 31 \mathrm{Mpa}$ and 22Mpa respectively. Similarly, fcm for retrofitted specimens Pure Compression Retrofitted (PCR1), PCR2 and PCR 3 was 24Mpa for each while fcm for jacket of PCR1, PCR2 and PCR 3 was 31Mpa, $43 \mathrm{Mpa}$ and $24 \mathrm{Mpa}$. The modulus of elasticity for steel used is $2.02 \times 10^{\wedge} 5 \mathrm{~N} / \mathrm{mm} 2$. The finite element model for the reference and retrofitted column was tested for under monotonically increasing compressive load. The failure load is obtained by creating load vs displacement plot as shown in Figure 5. Comparison for the failure loads obtained from the previous experimental study and the finite element analysis in this study is presented in Table 2 . 

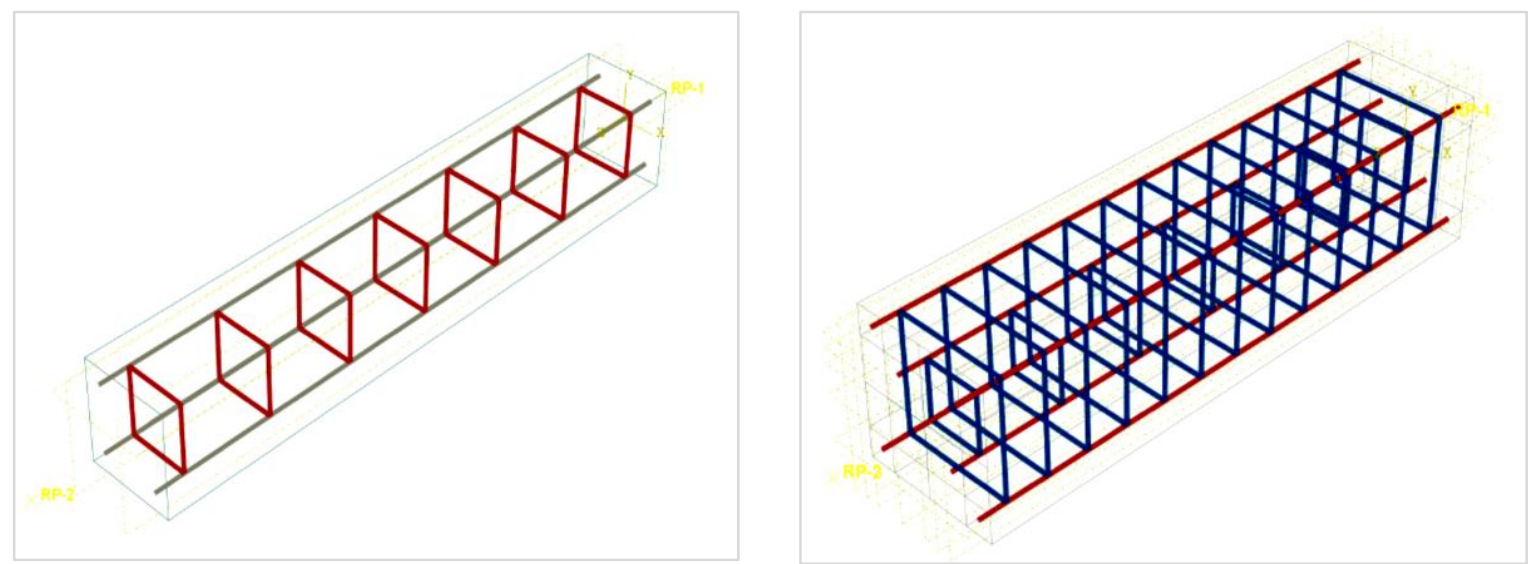

Figure 3 Finite element model of the reference column Figure 4 Finite element model of jacketed column

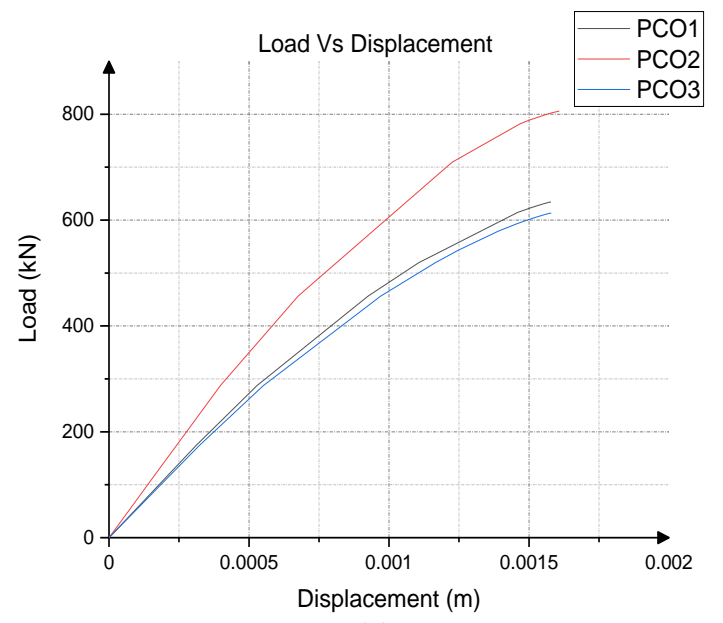

(a)

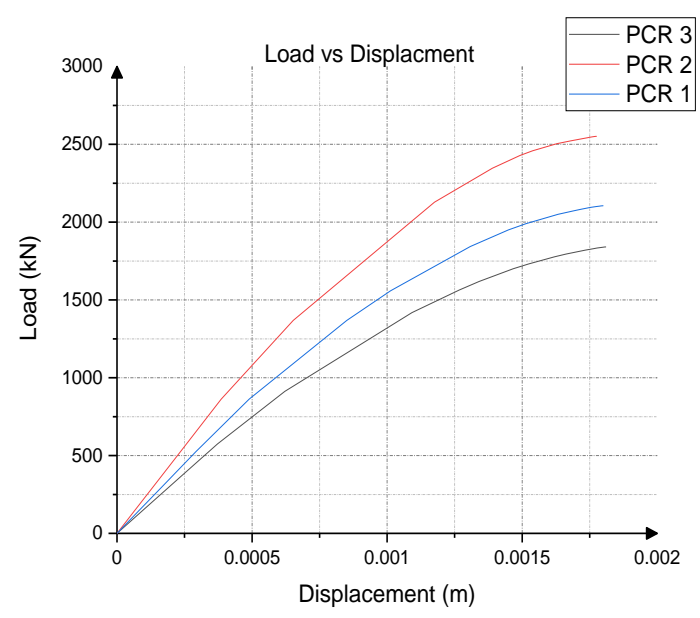

(b)

Figure 5 Load v/s displacement plots for (a) reference column models (b) jacketed column models

Table 2 Failure loads for reference and jacketed columns

\begin{tabular}{|c|c|c|c|}
\hline Specimen & $\begin{array}{l}\text { Failure load (kN) } \\
\text { (Experimental) [1] }\end{array}$ & $\begin{array}{lll}\begin{array}{l}\text { Failure load } \\
\text { simulation) }\end{array} & (\mathbf{k N}) & (\text { After } \\
\end{array}$ & Ratio \\
\hline PCO1 & 646 & 634.2 & 0.982 \\
\hline $\mathrm{PCO} 2$ & 720 & 805.7 & 1.119 \\
\hline $\mathrm{PCO} 3$ & 560 & 613.1 & 1.095 \\
\hline PCR1 & 1350 & 2104.8 & 1.559 \\
\hline PCR2 & 2150 & 2550 & 1.186 \\
\hline PCR3 & 1565 & 1840.4 & 1.176 \\
\hline
\end{tabular}

From Table 2, the surge in the load carrying capacity observed post-simulation is $231.8 \%, 216.5 \%$ and $200 \%$ for the PCR1, PCR2 and PCR3 columns as compared to $\mathrm{PCO} 1, \mathrm{PCO} 2$ and $\mathrm{PCO} 3$ respectively. Once the finite element model used was validated and proved to replicate the actual response of the RC column satisfactorily, analysis was carried forward to see the effect of different length and cross-section of the column and its behaviour post retrofitting. In further analysis the length of reference column used is $3 \mathrm{~m}$ with the cross section of $300 \mathrm{~mm}$ by $300 \mathrm{~mm}$ while 961 the thickness of jacket adopted is $100 \mathrm{~mm}$ which makes the cross-section of $500 \mathrm{~mm}$ by $500 \mathrm{~mm}$ for the jacketed column.

\section{Analysis of the column model}

This section includes the modelling and analysis results of a square column with 3 metre length, which will be strengthened by a $100 \mathrm{~mm}$ thick jacket [32] along all sides. The cross-section of the column is same as mentioned in Figure 1 and Figure 2. The first step in modelling is to create all the individual parts of 
the column. All different parts like column, reinforcement and jacket are created in this module. The column is created as a three-dimensional deformable solid by extrusion. Reinforcement is created as a three-dimensional deformable wire and jacket is created as a three-dimensional shell. The "deformable" option is chosen for all the parts; hence all parts can deform under the application of loads. When parts are created in the part module it exists in its coordinate system, independent of other parts in the model. While in the assembly module, when the instance of that part is created and positioned relative to another part instances, then we work in the assembly's global coordinate system. The parts and their instances are positioned properly to create an assembly as shown in Figure 6 and define the geometry of the finished model. Although a model may consist of many parts, but it will contain only one assembly. Characteristic compressive strength of concrete used for modelling the reference column is M20 whereas M25 is used for modelling the jacket. The grade of steel used is Fe415. The details of the material properties are mentioned in Table 3 . The best model believed to develop the behaviour of concrete is the CDP model. CDP properties used in the analysis are presented in Table 4. ABAQUS uses the symbol $\psi$ for expressing dilation angle, the plastic potential eccentricity of concrete $(\varepsilon)$, the ratio of compressive stress in the biaxial state to the compressive stress in the uniaxial state $\left(f_{b o} / f_{c}\right)$ and the shape factor of the yielding surface in the deviatoric plane $\left(\mathrm{K}_{c}\right)$.

The modelling, analysis procedure follows the same steps and methodology as discussed in the validation section. The existing and jacketed column will be tested under pure compression, eccentric compression and pure bending. Hereafter, the existing specimen shall be referred as Pure Compression Existing (PCE), Eccentric Compression Existing (ECE) and Pure Bending Existing (PBE) while the jacketed specimens shall be referred as Pure Compression Jacketed (PCJ), Eccentric Compression Jacketed (ECJ) and Pure Bending Jacketed (PBJ).

Table 3 Material properties

\begin{tabular}{|c|c|c|c|c|c|}
\hline \multirow[t]{2}{*}{ Type of Material } & \multirow{2}{*}{$\begin{array}{l}\text { Density } \\
\left(\mathrm{g} / \mathrm{cm}^{3}\right)\end{array}$} & \multirow{2}{*}{$\begin{array}{c}\text { Modulus } \\
\text { elasticity } \\
\text { (GPa) }\end{array}$} & \multirow{2}{*}{$\begin{array}{l}\text { Poisson's } \\
\text { Ratio (v) }\end{array}$} & \multicolumn{2}{|c|}{ Yield Stress of the material } \\
\hline & & & & $\begin{array}{l}\text { In Compression } \\
\text { (GPa) }\end{array}$ & $\begin{array}{l}\text { In Tension } \\
\text { (GPa) }\end{array}$ \\
\hline \multicolumn{6}{|l|}{ 1.Concrete } \\
\hline a. Column & 2.4 & 20 & 0.13 & .020 & .00315 \\
\hline b. Jacket & 2.4 & 20 & 0.13 & .025 & .0035 \\
\hline 2.Steel & 7.85 & 200 & 0.3 & 0.415 & \\
\hline
\end{tabular}

Table 4 CDP parameters [33]

\begin{tabular}{llll}
\hline $\boldsymbol{\Psi}$ & $\mathbf{K}_{\boldsymbol{c}}$ & $\boldsymbol{f}_{\boldsymbol{b o}} / \boldsymbol{f}_{\boldsymbol{c}}$ & $\boldsymbol{\varepsilon}$ \\
\hline 13 & 0.7 & 1.16 & 0.1 \\
\hline
\end{tabular}

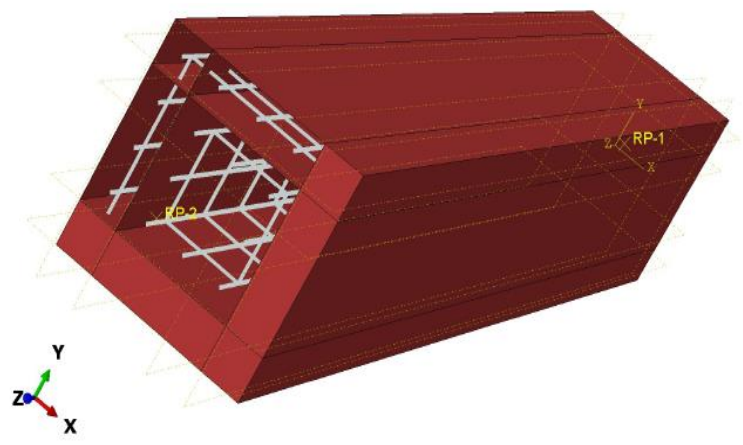

Figure 6 Assembling the parts (material view)

\subsection{Pure compression}

In order to test the column under pure compression, a monotonically increasing load is concentrically applied to the column. The model is utilized to determine the ultimate compressive failure load for the reference column and jacketed column. The failure load is determined with the help of load v/s displacement curve. To create the point of load application, a reference point has been generated at the centroid of the column face in the XY plane. The deformation contour for the reference and retrofitted column after the application of monotonically increasing load is shown in Figure 7. With the help of this deformation contour, a plot of load v/s displacement curve under axial loading is generated which is presented in Figure 8.

From the plot in Figure 8 failure load for the existing column under pure compression comes out to be $1801 \mathrm{kN}$ whereas for the jacketed column under pure compression failure load is $4480 \mathrm{kN}$ which is 2.48 times of the reference model. 


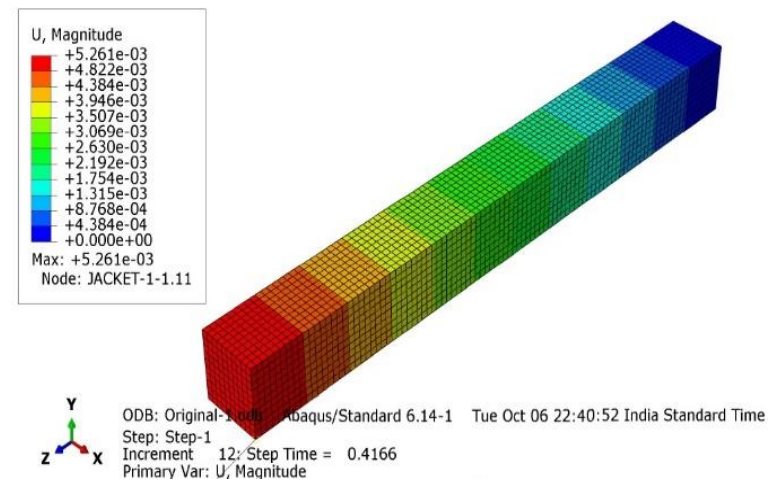

(a)

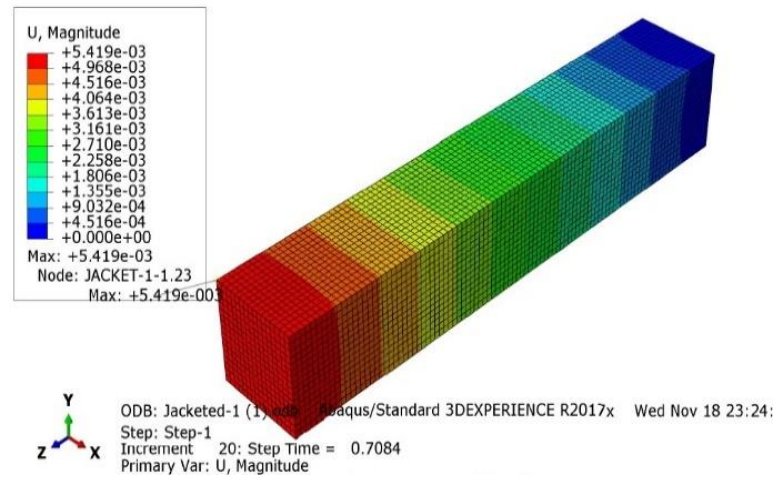

(b)

Figure 7 Deformation contours of the reference column (a) and jacketed column (b) under pure compression

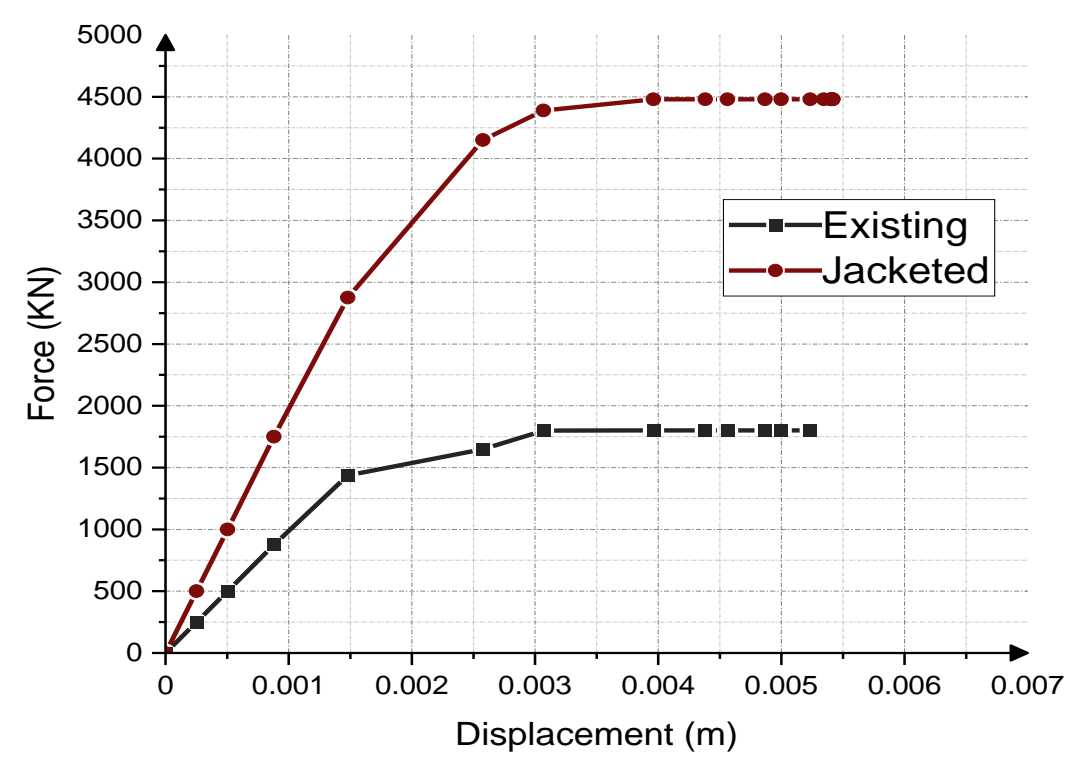

Figure 8 Force v/s displacement curves under pure compression

\subsection{Eccentric compression}

A cross-section subjected to axial force along with bending is referred as eccentric compression. In this analysis, uniaxial eccentricity has been considered to compare the performance of reference and jacketed columns. The value of eccentricity considered for the reference column is $50 \mathrm{~mm}$ whereas e value for jacketed column is kept as $100 \mathrm{~mm}$ which becomes a case of small eccentricity as e is less than D/4 i.e., 300/4 (reference column) and 500/4 (jacketed column). To create the point of load application a reference point has been generated at the top face of the column at a specified location. Cross-section and point of load application for both the columns are shown in Figure 9. Value of eccentricity in taken at the column face in the direction of positive $\mathrm{X}$-axis. The deformation contour for the reference and retrofitted column after the application of monotonically increasing load is shown in Figure 10. Due to the eccentricity, one side of the column in YZ plane experiences compression while the other side experiences tension. With the help of this deformation contour, a plot of load v/s displacement and moment $\mathrm{v} / \mathrm{s}$ rotation curve under eccentric loading is generated which is presented in Figure 11 and Figure 12 respectively. From the plot in Figure 11 failure load for the existing column under eccentric compression comes out to be $1003.6 \mathrm{kN}$ whereas for the jacketed column failure load is $3880 \mathrm{kN}$ which is 3.86 times of the reference model. In the similar manner, the ultimate moment for the existing column under eccentric compression is $63 \mathrm{kNm}$ which becomes $386.58 \mathrm{kNm}$ after jacketing. This increase in the ultimate moment after RC jacketing is around 6 times than that of the existing column. 
Praveen Anand et al.

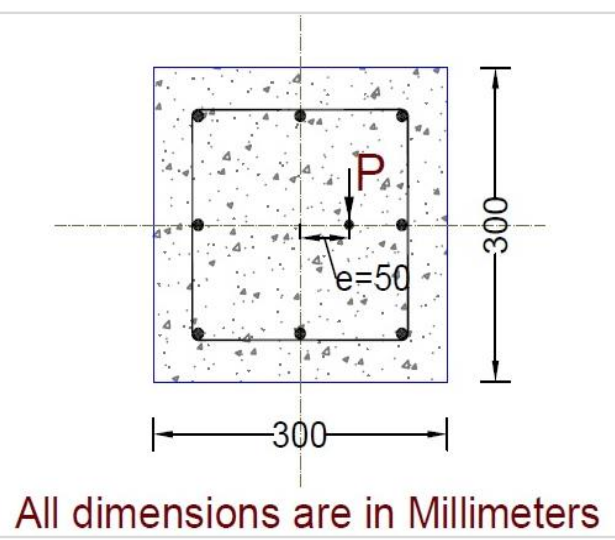

(a)

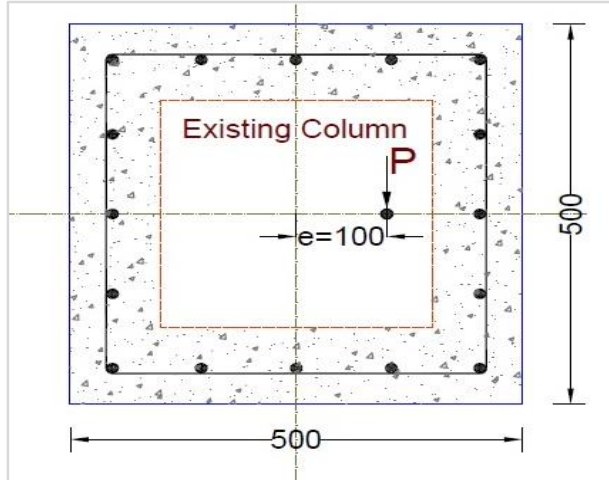

All dimensions are in Millimeters

(b)

Figure 9 Cross-section of the (a) reference and (b) jacketed column with the point of eccentric load application

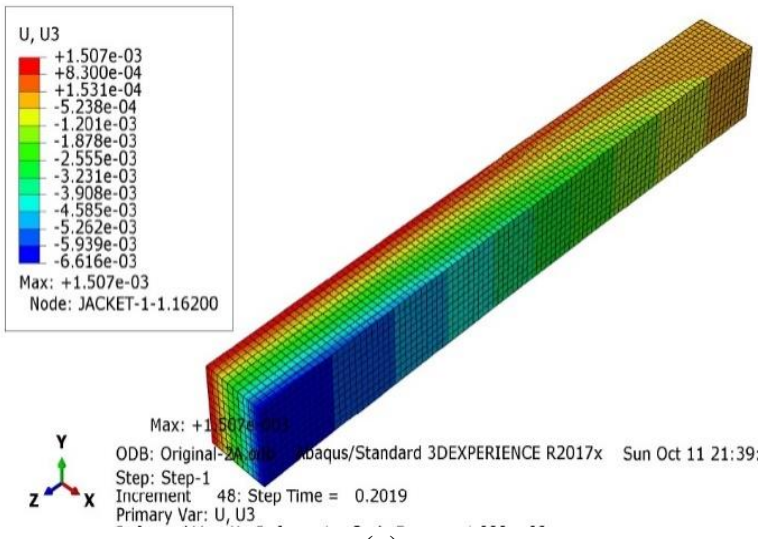

(a)

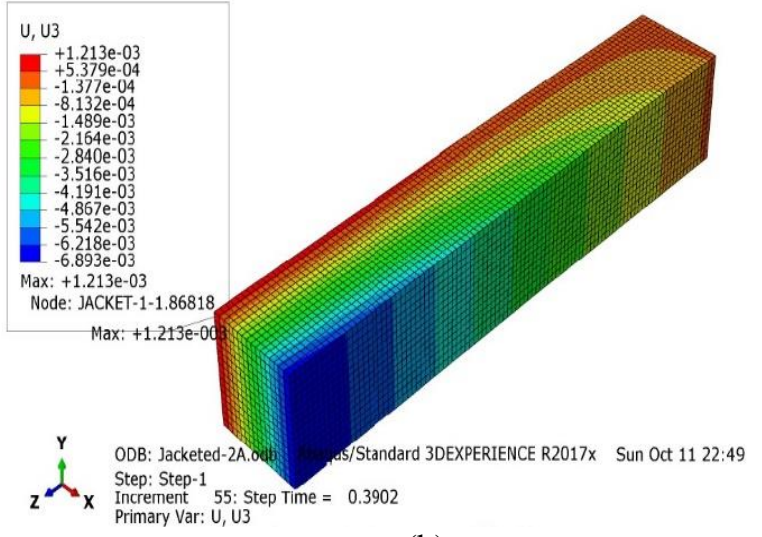

(b)

Figure 10 Deformation contours of the reference column (a) and jacketed column (b) under eccentric compression

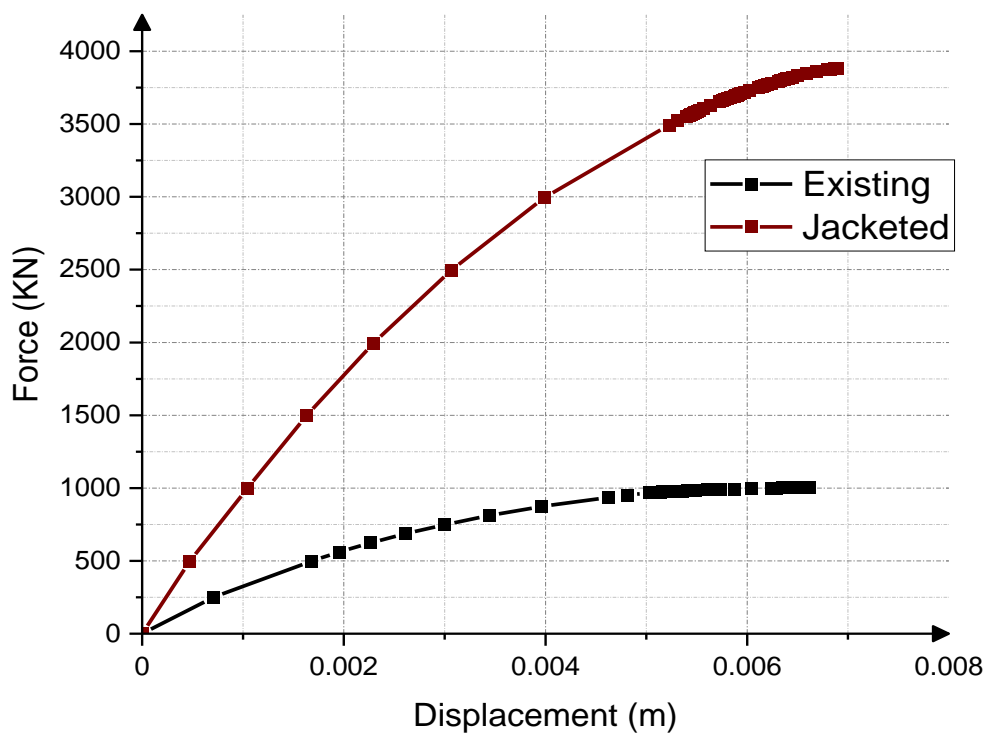

Figure 11 Force v/s displacement curves under eccentric compression 


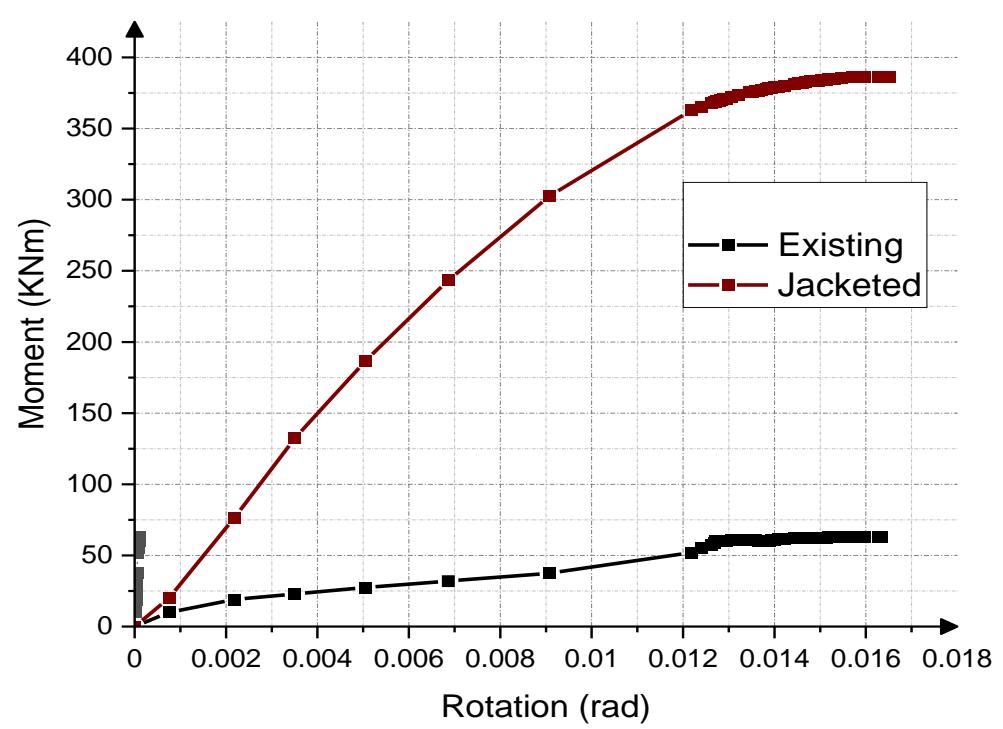

Figure 12 Moment v/s rotation curves under eccentric compression

\subsection{Pure bending}

To test the performance of the column under the effect of lateral load, bending test was performed by loading at two points. Steel plates of $25 \mathrm{~mm}$ thickness were attached at the top and bottom at respective locations to apply the load and establish the boundary condition. The plates were modelled as rigid elements with young's modulus of $21,0000 \mathrm{MPa}$ and a density of $7850 \mathrm{kN} / \mathrm{m} 3$. The setup and loading pattern for bending test through finite element analysis is shown in Figure 13. The bottom supports are provided at a distance of $300 \mathrm{~mm}$ from the face of the column, which makes the clear distance between the supports of $2400 \mathrm{~mm}$. The point of application of load is kept as $1 / 3$ rd of clear distance i.e., $800 \mathrm{~mm}$ from the supports. Analysis was carried under two-point load with each point load $800 \mathrm{~mm}$ away from the support the

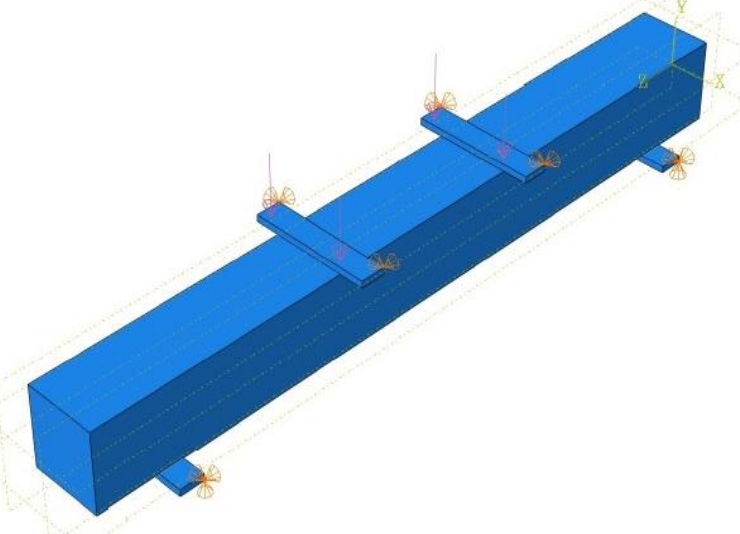

(a) magnitude of which was being increased monotonically till the ultimate load is achieved. The deformation contour for the reference and retrofitted column after the application monotonically increasing load is shown in Figure 14. The region under the points of load application experiences maximum deformation. With the help of this deformation contour, a plot of moment $\mathrm{v} / \mathrm{s}$ rotation under bending loading is generated which is presented in Figure 15.

From Figure 15 the ultimate moment for the existing column under pure bending is $37.5 \mathrm{kNm}$ which becomes $138 \mathrm{kNm}$ after jacketing. This increase in the ultimate moment after RC jacketing is around 3.68 times than that of the existing column.

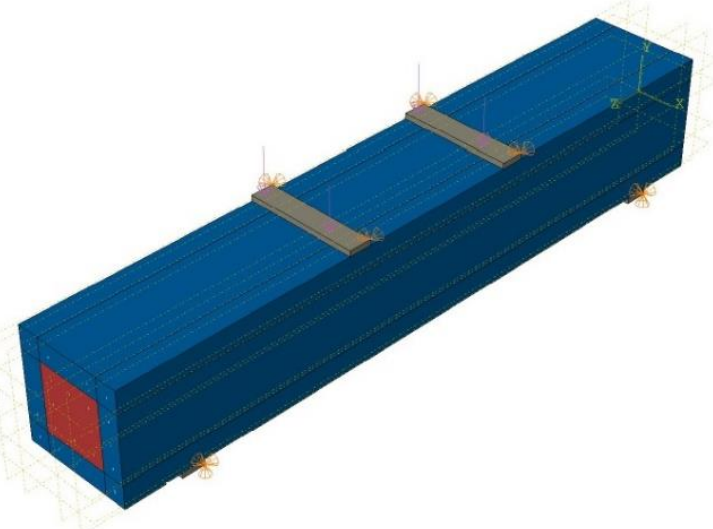

(b)

Figure 13 Finite element model setup of (a) reference column (b) jacketed column for pure bending test 


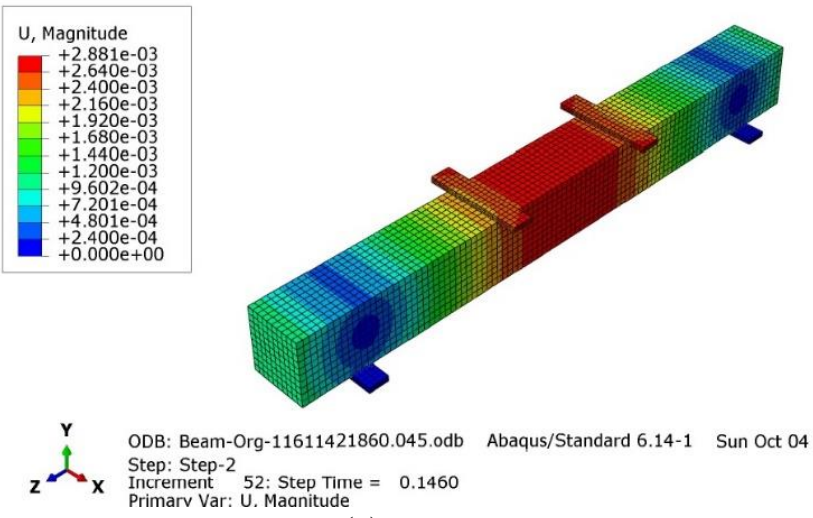

(a)

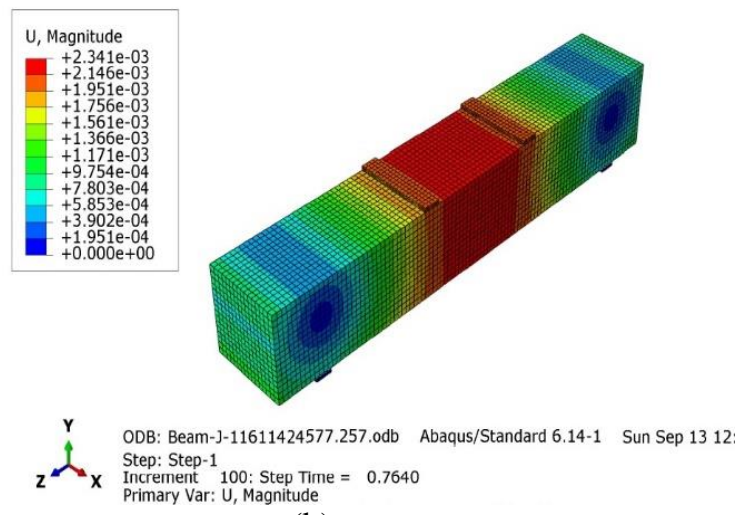

(b)

Figure 14 Deformation contours of the reference column (a) and jacketed column (b) under pure bending

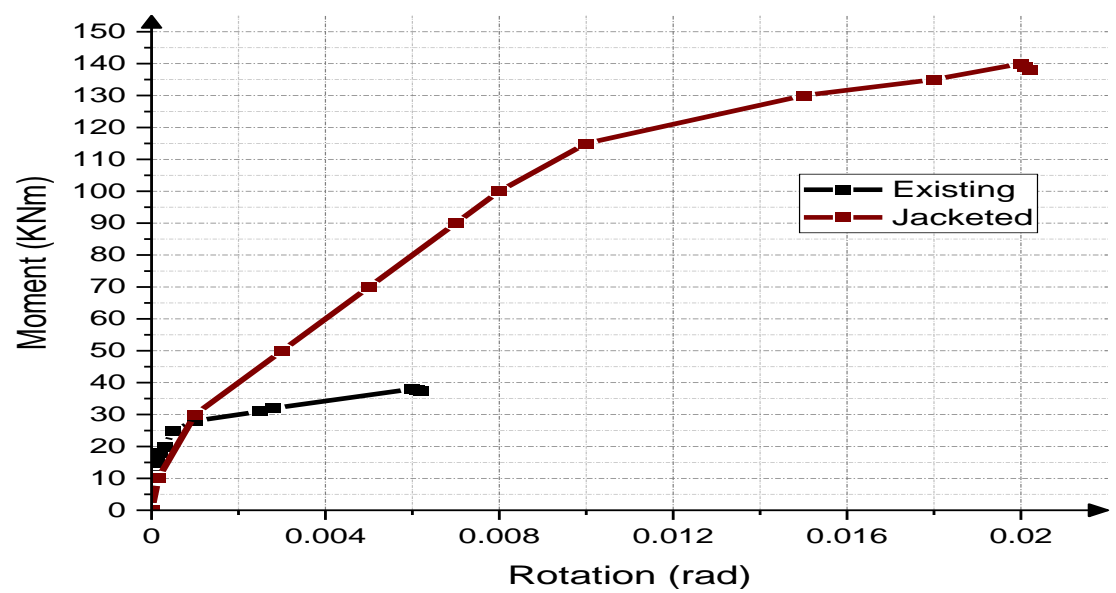

Figure 15 Moment v/s rotation curve under pure bending

\section{Results}

The confinement provided by the adding RC layer increases the strength of the existing column significantly. Comparative analysis of the existing and jacketed column is presented in Table 5. For the columns under pure compression the parameter used for making comparative analysis was failure load. For the columns under eccentric compression the parameter used for making comparative analysis was failure load as well as ultimate moment. Similarly, for the columns under pure bending the parameter used for making comparative analysis was ultimate moments only.

Table 5 Failure loads and ultimate moments of column specimens

\begin{tabular}{llll}
\hline Type of specimen & Specimen designation & Failure load $(\mathbf{k N})$ & Ultimate moment $(\mathbf{k N m})$ \\
\hline \multirow{2}{*}{ Exiting } & PCE & 1801 & - \\
\cline { 2 - 4 } & ECE & 1003.6 & 63 \\
\cline { 2 - 4 } & PBE & - & 37.5 \\
\hline \multirow{2}{*}{ Jacketed } & PCJ & 4480 & - \\
\cline { 2 - 4 } & ECJ & 3880 & 386.58 \\
\cline { 2 - 4 } & PBJ & - & 138 \\
\hline
\end{tabular}

From the data presented in Table 5 it can be clearly noticed, the failure load for column under pure compression is $1801 \mathrm{kN}$ which increases to $4480 \mathrm{kN}$ after jacketing taking the percentage surge to
148.75\%. Also, under eccentric compression failure load is $1003.6 \mathrm{kN}$ before jacketing and increases to $3880 \mathrm{kN}$ after RC jacketing making the percentage surge of $286.60 \%$. Similarly, the ultimate moment for 
the model under eccentric compression increases to $386.58 \mathrm{kNm}$ from $63 \mathrm{kNm}$ after jacketing making a percentage increase of $513.6 \%$. Also, under pure bending the ultimate moment increases to $138 \mathrm{kNm}$ from $37.5 \mathrm{kNm}$ after $\mathrm{RC}$ jacketing showing an increase of $268 \%$. The finite element results obtained from ABAQUS in terms of load-deflection curves and moment rotation curves were found to be consistent with the experimental results obtained from the literature.

\section{Discussion}

Under the influence of axial load, the load carrying capacity of the jacketed frame column increased significantly i.e., the strength is improved. The jacketed column model showed a substantial increase in the load carrying capacity and ultimate moment under eccentric loading also. The ultimate moment limits of the jacketed column under bending were generously more than those of the existing columns thus showing a significant increase in the lateral strength of the column.

The scope of this research is limited to square columns with a medium grade of concrete where M20 has been used for the existing column and M25 for the RC jacket. It is suggested that for the construction of the RC jacket use of High-Performance Concrete (HPC) shall be preferred. The effect of preloading on the columns has not been considered. Therefore, the column analysed in this study was in undamaged condition which may result in overestimation of failure loads after RC jacketing. Since the proposed method is hypothetical, an experimental validation of the same cannot be performed due to unavailability of hardware and testing facilities. Complete list of abbreviations is shown in Appendix I.

\section{Conclusion and future work}

Our result suggests RC jacketing shows a tremendous increase in load carrying capacity of columns as compared to steel jacketing and FRP wrapping. This can be attributed to the fact that RC jacketing is able to provide a better composite behaviour. Comparative analysis for both cases has been performed. Analysis performed in ABAQUS was able to predict such an increase in capacity. The models were able to determine and predict the behaviour of the jacketed column with a very reasonable error level.

$\mathrm{RC}$ jacketing on a square column has resulted in a significant increase in the load carrying capacity. However, further investigations may be carried out on circular and rectangular columns by varying the parameters associated with concrete and steel such as concrete grade, percentage of reinforcement, spacing of ties in the jacket. Such investigation can help in determining the optimum percentage of reinforcement and spacing of lateral ties for the RC jacket. Methods involving roughened surfaces or even with no surface treatment can be compared and used to demonstrate the efficiency of the interface mechanisms. Furthermore, the simulation carried out in ABAQUS only presents the idea and behaviour of the undamaged columns after jacketing. However, to find out practical solutions damaged columns shall be considered for jacketing. Exploring all possible aspects and including more parametric studies can help in achieving better insights to the technique. It can provide a clearer understanding of the possible outcomes.

\section{Acknowledgment}

None.

\section{Conflicts of interest}

The authors have no conflicts of interest to declare.

\section{References}

[1] Kaliyaperumal G, Sengupta AK. Seismic retrofit of columns in buildings for flexure using concrete jacket. ISET Journal of Earthquake Technology. 2009; 46(2):77-107.

[2] Raza S, Khan MK, Menegon SJ, Tsang HH, Wilson JL. Strengthening and repair of reinforced concrete columns by jacketing: state-of-the-art review. Sustainability. 2019; 11(11):1-31.

[3] Farrokh GH, Comert M, Demir C, Akbaba M, Ilki A. Seismic retrofit of full-scale substandard extended rectangular RC columns through CFRP jacketing: test results and design recommendations. Journal of Composites for Construction. 2019; 23(1).

[4] Shang XY, Yu JT, Li LZ, Lu ZD. Strengthening of RC structures by using engineered cementitious composites: a review. Sustainability. 2019; 11(12):118.

[5] Zhou C, Li X, Wang D, Xia S. Analysis of bearing capacity and seismic performance of circular RC columns strengthened with externally wrapped steel plates. Advances in Civil Engineering. 2019:1-17.

[6] Li W, Liang H, Lu Y, Xue J, Liu Z. Axial behavior of slender RC square columns strengthened with circular steel tube and sandwiched concrete jackets. Engineering Structures. 2019; 179:423-37.

[7] Villar-salinas S, Guzmán A, Carrillo J. Performance evaluation of structures with reinforced concrete columns retrofitted with steel jacketing. Journal of Building Engineering. 2021.

[8] Ganesan G, Kumaran G. An experimental study on the behaviour of GFRP pultruded I beam reinforced with CFRP laminates. International Journal of Advanced Technology and Engineering Exploration. 2018; 5(45):232-42. 
[9] Anand P, Sinha AK. Strengthening of reinforced concrete column by glass fiber reinforced polymer jacketing. International Journal of Advanced Research in Engineering and Technology.2020; 11(7): 686-96.

[10] Noroozieh E, Mansouri A. Lateral strength and ductility of reinforced concrete columns strengthened with NSM FRP rebars and FRP jacket. International Journal of Advanced Structural Engineering. 2019; 11:195-209.

[11] Rodriguez M, Park R. Seismic load tests on reinforced concrete columns strengthened by jacketing. Structural Journal. 1994; 91(2):150-9.

[12] Vaghani MV, Vasanwala SA, Desai AK. Advanced retrofitting techniques for $\mathrm{RC}$ building: a state of an art review. International Journal of Current Engineering and Technology. 2014; 4(2):579-84.

[13] Tayeh BA, Naja MA, Shihada S, Arafa M. Repairing and strengthening of damaged RC columns using thin concrete jacketing. Advances in Civil Engineering. 2019:1-16.

[14] Huang H, Huang M, Zhang W, Wu T. Seismic behavior of strengthened square reinforced concrete columns under combined loadings. Structure and Infrastructure Engineering. 2019; 15(11):1468-84.

[15] Alsomiri M, Jiang X, Liu Z. Elastic restraint effect of concrete circular columns with ultrahigh-performance concrete jackets: an analytical and experimental study. Materials. 2021; 14(12):1-20.

[16] Zaiter A, Lau TL. Experimental study of jacket height and reinforcement effects on seismic retrofitting of concrete columns. Structures 2021;31:1084-95. Elsevier.

[17] Stoppenhagen DR, Jirs JO, Wyllie LA. Seismic repair and strengthening of a severely damaged concrete frame. Structural Journal. 1995; 92(2):177-87.

[18] Abu-tair AI, Rigden SR, Burley E. Testing the bond between repair materials and concrete substrate. Materials Journal. 1996; 93(6):553-8.

[19] Austin S, Robins P, Pan Y. Shear bond testing of concrete repairs. Cement and Concrete Research. 1999; 29(7):1067-76.

[20] Julio ES, Branco F, Silva VD. Structural rehabilitation of columns with reinforced concrete jacketing. Progress in Structural Engineering and Materials. 2003; 5(1):2937.

[21] Beushausen H, Alexander MG. Bond strength development between concretes of different ages. Magazine of Concrete Research. 2008; 60(1):65-74.

[22] Clímaco JD, Regan PE. Evaluation of bond strength between old and new concrete in structural repairs. Magazine of Concrete Research. 2001; 53(6):377-90.

[23] Julio EN, Branco FA. Reinforced concrete jacketinginterface influence on cyclic loading response. ACI Structural Journal. 2008; 105(4):1-7.
[24] Gholampour A, Hassanli R, Mills JE, Vincent T, Kunieda M. Experimental investigation of the performance of concrete columns strengthened with fiber reinforced concrete jacket. Construction and Building Materials. 2019; 194:51-61.

[25] Alcocer SM. RC frame connections rehabilitated by jacketing. Journal of Structural Engineering. 1993; 119(5):1413-31.

[26] Júlio EN, Branco FA, Silva VD. Reinforced concrete jacketing-interface influence on monotonic loading response. ACI Structural Journal. 2005; 102(2):252-7.

[27] Vandoros KG, Dritsos SE. Concrete jacket construction detail effectiveness when strengthening RC columns. Construction and Building Materials. 2008; 22(3):26476.

[28] Lampropoulos AP, Dritsos SE. Modeling of RC columns strengthened with RC jackets. Earthquake Engineering \& Structural Dynamics. 2011; 40(15):1689-705.

[29] Al-dwaik MM, Armouti NS. Analytical case study of seismic performance of retrofit strategies for reinforced concrete frames: steel bracing with shear links versus column jacketing. Jordan Journal of Civil Engineering. 2013; 7(1):26-43.

[30] Dritsos S, Moseley J. Monolithic coefficient design values for seismically strengthening RC columns with jackets. Ce/Papers. 2019; 3(2):172-6.

[31] Anand P, Sinha AK. Effect of reinforced concrete jacketing on axial load capacity of reinforced concrete column. Civil Engineering Journal. 2020; 6(7):126672.

[32] Tayeh BA, Abu BBH, Megat JMA, Ratnam MM. Existing concrete textures: their effect on adhesion with fibre concrete overlay. Proceedings of the Institution of Civil Engineers-Structures and Buildings. 2014; 167(6):355-68.

[33] Lopez-almansa F, Alfarah B, Oller S. Numerical simulation of RC frame testing with damaged plasticity model, comparison with simplified models. In second European conference on earthquake engineering and seismology, Istanbul 2014 (pp. 1-12).

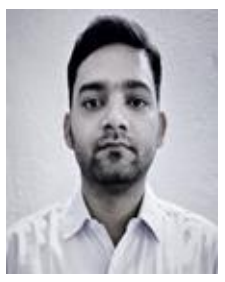

Praveen Anand received his B.Tech degree in Civil Engineering in 2015 from West Bengal University of Technology, India. He pursued his M.Tech with specialization in structural engineering from National Institute of Technology, Patna. Presently he is pursuing his Ph.D from National Institute of Technology, Patna. He has also been associated with Earthquake Safety and Clinic Centre (EQSC) at NIT, Patna. His area of interest includes Retrofitting and Strengthening, Vulnerability Assessment and Seismic Analysis of Structures.

Email: praveen.ce16@nitp.ac.in 


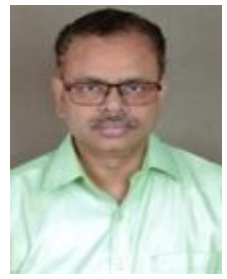

Ajay Kumar Sinha is presently Professor, Civil Engineering Department, National Institute of Technology Patna. He has 35 years of teaching and research experience. He obtained his B.Tech degree from IIT BHU in 1986, M.E. in Earthquake Engineering from IIT Roorkee in 1989. He completed his PhD from Delhi College of Engineering, University of Delhi. His research interests include Seismic resistant structures, Vulnerability Assessment and Retrofitting of structures, Structural Health Monitoring, Reliability Engineering. He is centre Director cum Nodal Officer of Earthquake safety Clinic and Centre at NIT Patna. $\mathrm{He}$ is a member of the Earthquake Committee of BSDMA, GoB, Patna. He has published over 150 research Papers in National and International journals and conferences. He has supervised $5 \mathrm{PhD}$ and $55 \mathrm{ME}$ students with $10 \mathrm{PhDs}$ undergoing.

Email: aksinha@nitp.ac.in

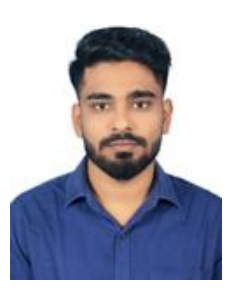

Chandan Kumar was born on March 6, 1998 in Patna Bihar, India. He is currently pursuing his Ph.D in Civil Engineering from National Institute of Technology, Patna, Bihar, India. He is also a member of the Earthquake Safety Clinic and Centre (EQSC), National Institute of Technology, Patna, Bihar, India and co-ordinates and manages day to day functioning of the centre. He obtained his M. Tech Degree in Structural Engineering from National Institute of Technology, Patna in 2021, B.Tech in Civil Engineering in 2019 and Diploma in Civil Engineering in 2016. His Research activities include Retrofitting, Multi Hazard Resilience, Structural Safety Audit and Seismic Vulnerability Assessment.

Email: chandank.pg19.ce@nitp.ac.in

\begin{tabular}{lll}
$\begin{array}{l}\text { Appendix I } \\
\text { S. No. }\end{array}$ & Abbreviation & Description \\
\hline 1 & CDP & Concrete Damaged Plasticity \\
\hline 2 & CFRP & $\begin{array}{l}\text { Carbon Fibre Reinforced } \\
\text { Polymer }\end{array}$ \\
\hline 3 & ECC & $\begin{array}{l}\text { Engineered Cementitious } \\
\text { Concrete }\end{array}$ \\
\hline 4 & ECE & $\begin{array}{l}\text { Eccentric Compression } \\
\text { Existing }\end{array}$ \\
\hline 5 & ECJ & $\begin{array}{l}\text { Eccentric Compression } \\
\text { Jacketed }\end{array}$ \\
\hline 6 & FRP & Fibre Reinforced Polymer \\
\hline 7 & GFRP & $\begin{array}{l}\text { Glass Fibre Reinforced } \\
\text { Polymer }\end{array}$ \\
\hline 8 & HFRP & $\begin{array}{l}\text { Hybrid Fibre Reinforced } \\
\text { Polymer }\end{array}$ \\
\hline 9 & HPC & High Performance Concrete \\
\hline 10 & MPC & Multi Points Constraints \\
\hline 11 & NSM & Near Surface Mounted \\
\hline 12 & PBE & Pure Bending Eccentric \\
\hline 13 & PBJ & Pure Bending Jacketed \\
\hline 14 & PCE & Pure Compression Existing \\
\hline 15 & PCJ & Pure Compression Jacketed \\
\hline 16 & PCO & Pure Compression Original \\
\hline 17 & PCR & Pure Compression Retrofitted \\
\hline 18 & RC & Reinforced Concrete \\
\hline & &
\end{tabular}

